Document downloaded from:

http://hdl.handle.net/10251/141950

This paper must be cited as:

Moreno Trigos, MY.; Moreno-Mesonero, L.; García Hernández, J. (09-2). DVC-FISH to identify potentially pathogenic Legionella inside free-living amoebae from water sources. Environmental Research. 176:1-7. https://doi.org/10.1016/j.envres.2019.06.002

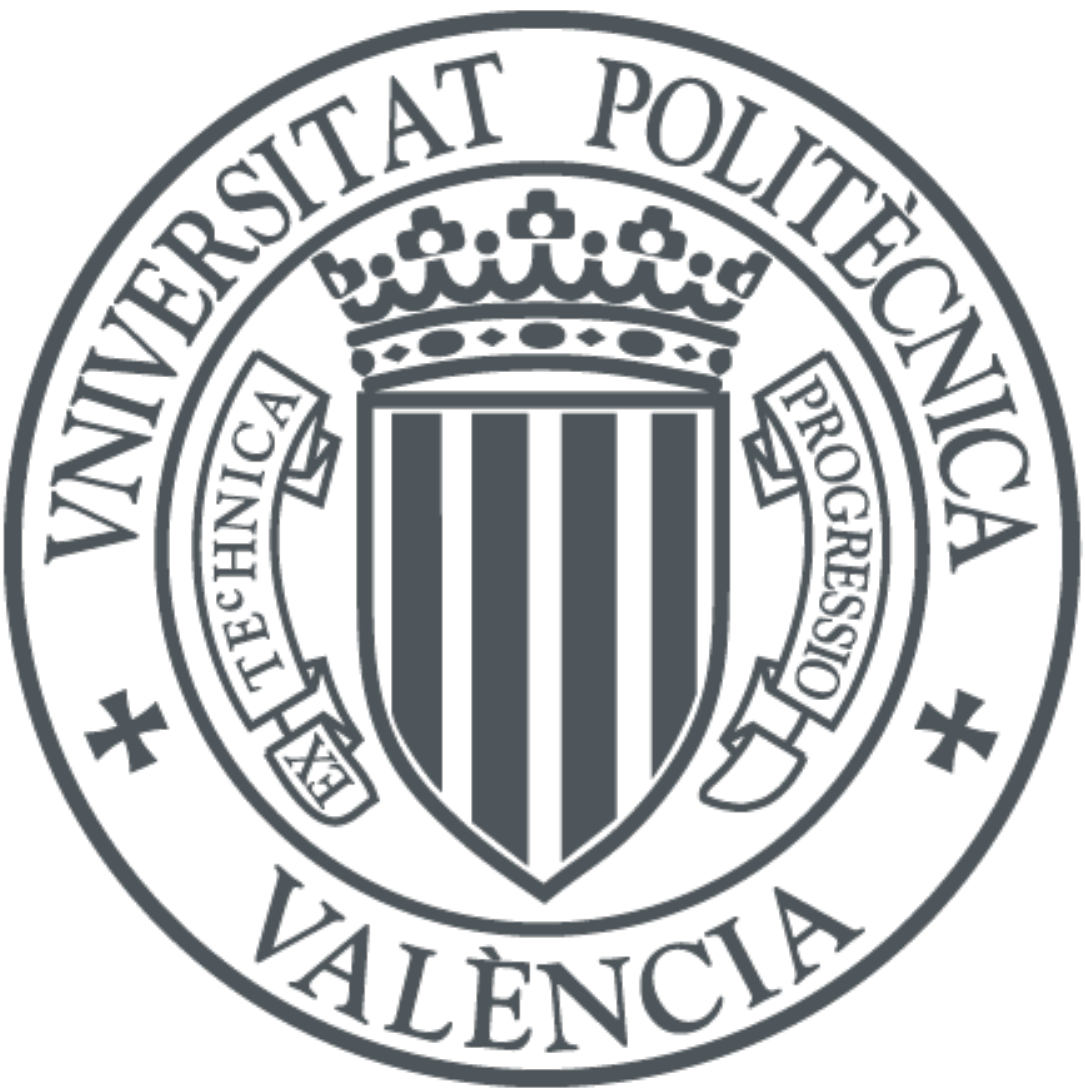

The final publication is available at

https://doi.org/10.1016/j.envres.2019.06.002

Copyright Elsevier

Additional Information 
1 DVC-FISH to identify potentially pathogenic Legionella inside Free-Living

2 Amoebae from water sources

3

4 Moreno, Y.a ${ }^{a^{*}}$, Moreno-Mesonero, L. ${ }^{a^{*}}$, García-Hernández, J. ${ }^{b}$

5

6 aResearch Institute of Water and Environmental Ingeneering (IIAMA), Universitat

7 Politècnica de València, 46022 Valencia, Spain

8 bBiotechnology Department, Universitat Politècnica de València, 46022 Valencia,

9 Spain

10

$11 *$ These authors contributed equally to this work

12

13 For correspondence: Yolanda Moreno. E-mail: ymoren@upv.es ; Tel (+34)

14 963879797; Research Institute of Water and Environmental Engineering (IIAMA),

15 Universitat Politècnica de València, Camino de Vera s/n, 46022 Valencia, Spain.

16 
Despite all safety efforts, drinking and wastewater can still be contaminated by Legionella and free-living amoebae since these microorganisms are capable of resisting disinfection treatments. An amoebae cyst harboring pathogenic Legionella spp. can be a transporter of this organism, protecting it and enhancing its infection abilities. Therefore, the aim of this work is to identify by DVC-FISH viable Legionella spp and Legionella pneumophila cells inside FLA from water sources in a specific and rapid way with the aim of assessing the real risk of these waters.

A total of 55 water samples were processed, 30 reclaimed wastewater and 25 drinking water). FLA presence was detected in $52.7 \%$ of the total processed water samples. When DVC-FISH technique was applied, the presence of viable internalized Legionella spp. cells was identified in $69.0 \%$ of the total FLA-positive samples, concretely in $70.0 \%$ and $66.7 \%$ of wastewater and drinking water samples, respectively. L. pneumophila was simultaneously identified in $48.3 \%$ of the total FLA-positive samples, specifically in $50.0 \%$ and $44.4 \%$ of wastewater and drinking water samples, respectively.

By culture, potentially pathogenic Legionella cells were recovered in $27.6 \%$ of the total FLA-positive bacteria, particularly in $35.0 \%$ and $11.1 \%$ of wastewater and drinking water samples, respectively.

These findings demonstrate that FLA may promote resistance of bacteria to the performed disinfection treatments for drinking as well as for wastewater. So, in addition to the risk for the presence of pathogenic FLA in water it is necessary to take into account that these can be transporters of the pathogenic bacteria Legionella, which are able to survive inside them. The DVC-FISH method described here has been proved to be a rapid and specific tool to identify pathogenic Legionella spp. and L. penumophila viable cells harboured by FLA in these water sources, posing particular public health concern.

Keywords: Free-living amoebae, Legionella spp., DVC-FISH, wastewater, drinking 47 water 


\section{FUNDING SOURCE}

49 This study has been supported by First research projects funding (PAID-06-18),

50 Vice-Rectorate for Research, Innovation and Transfer of "Universitat Politècnica de 51 València" (UPV), València, Spain

52 


\section{INTRODUCTION}

The bacterial genus of Legionella includes more than 50 described species, of which at least 20 of them are associated with human disease (Burstein et al., 2016). It is an opportunistic pathogen that mainly affects immunocompromised individuals or people suffering from other diseases, exceptionally producing asymptomatic infections in the healthy population. Legionella spp. includes microorganisms which are found in natural aquatic habitats and whose ecological niches are surface water of rivers, lakes, ponds, streams, hot springs, or even the stagnant water near volcanoes or the Antarctica's lakes (Scaturro et al., 2016; Borella et al., 2004; Borella et al., 2005). Therefore, it is possible to find it in any aquatic habitat aside from estuaries and saline water (Graells et al. 2018).

Legionellosis, the disease caused by Legionella, has a high media impact when associated with community outbreaks, usually related to hot sanitary water, cooling towers, hot tubs or ornamental fountains (Gomez-Valero et al., 2014; Scaturro et al., 2016). Legionella pneumophila specie is included in the water contaminant candidate list 4 (CCL4), from the United States Environmental Protection Agency (US EPA). There are other Legionella species considered pathogenic among which Legionella micdadei, Legionella longbeachae, Legionella dumoffii and Legionella bozemanii can be found (Bartram et al., 2007; Lau and Ashbolt, 2009).

The significance of the study of Legionella spp. does not only focus on its important health implications but also needs to encompass the socio-economic ones, since it affects important sectors such as tourism, trade or petrochemicals (Borella et al., 2004). The circumstances that contribute to the spread of Legionella spp. are temperature in the range of $25-45^{\circ} \mathrm{C}$, with an ideal temperature of $35-37^{\circ} \mathrm{C}$, the existence of stagnant or low velocity of circulation water, the presence of nutrients, a suspended solids deposit, a rough surface with calcified deposits and corrosion and the creation of biofilms in the presence of protozoa, bacteria or algae (Moens, 2002).

Free-living amoebae (FLA) are environmental protozoa that have been isolated from almost all environmental sources (Trabelsi et al., 2012). Members of the species of Acanthamoeba are the most common FLA found in water, soil and air 
environments (Khan, 2006). Typically, FLA have two stages in their life cycle: the trophozoite, which is the metabolically active form, and the cyst, which is the dormant form and is acquired under unfavourable circumstances. While FLA are in favourable environmental conditions (trophozoite stage), one type of food they feed on is bacteria, some of which are able to avoid phagocytation and the ones phagocytised can even replicate inside FLA, becoming either commensal symbionts or even parasites. Thus, these bacteria would be sheltered and kept safe from stressed environmental conditions. For this reason, FLA have been considered as “Trojan Horses” (Barker and Brown, 1994) for these amoeba-resistant bacteria (ARB) (Greub and Raoult, 2004). Indeed, it has been extensively studied that human pathogens, such as Legionella, Listeria and Campylobacter can be potentially transmitted through FLA (Akya et al., 2009; Bui et al., 2012; Conza et al., 2013).

As it has been previously stated, some bacteria are able to escape protozoan phagocytation due to their inherent characteristics, such as virulence factors, toxin production or simply their size. However, some other bacteria can be ingested but have evolved strategies not only to evade digestion but also to multiply within protozoa, being the most studied example L. pneumophila which have used its interaction with FLA as learning to be able to infect macrophages (Cirillo et al., 1999; Adiba et al., 2010; Bui et al., 2012).

Up to now, little number of studies have investigated the interaction between FLA and Legionella spp. in environmental samples (Conza et al., 2013). However, Legionella have been found in aquatic environments such as drinking water or reclaimed wastewater systems, either in planktonic form, attached to a biofilm or related to protozoa (Declerck et al., 2007). Thus, FLA may play a role in the proliferation and the protection of Legionella against disinfection processes, which could serve as a carrier in the transmission of the Legionnaires' disease. Legionella spp. are highly pleomorphic bacteria which can actively replicate or be found in their stationary phase form in an extracellular nutrient-rich environment or a biofilm (Byrne and Swanson, 1998; Robertson et al., 2014). Similarly, when Legionella spp. are inside FLA or human macrophages they can acquire the replicative phase form until nutrients are depleted, at which time they differentiate into the infectious form inside FLA or macrophages (Garduño et al., 2002; Abdelhady and Garduño, 2013). 
The official and internationally accepted method for Legionella spp. detection in water samples (ISO 11371) is based on cultivation. The main drawbacks of cultivation method are considerable time required for the assay (10 days) and that it only allows the detection of colony-forming cells. Nowadays, this delay is unacceptably long, and a sensitive, specific and fast screening method is of much importance. (Füchslin et al., 2010)

The exposure to stress can induce gram-negative bacteria in the water environment to enter the viable but non-culturable (VBNC) state as a survival strategy (Oliver, 2010), which can be induced by different stressors. Some of these stressors are heat, starvation or chemical treatments such as chlorination (Steinert et al., 1997; García et al., 2007; Allegra et al., 2008). Due to all this, the evaluation of the viability of the pathogen by culture is an arduous task.

The combination of Direct Viable Count technique with FISH (DVC-FISH) has been reported as an efficient method to successfully detect viable and VBNC cells of some pathogenic microorganisms such as Helicobacer pylori (Tirodimos et al., 2014; Moreno and Ferrús, 2012). However, this technique has never been developed and applied to Legionella spp. identification. The advantages of DVCFISH are that it does not require DNA extraction and there are non-specific binding problems or inhibitory substances hindering hybridization. Moreover, FISH combines the visual information of microscopy to the accuracy of molecular genetics, allowing the visualization and identification of individual microbial cells in their native microenvironment. Nevertheless, FISH technique cannot differentiate between viable and dead cells without the combination with DVC incubation. DVC is a method based on samples' incubation in a nutrient-rich broth medium with the presence of an antimicrobial agent (quinolones antibiotics) (Kogure et al., 1979). This antimicrobial agent acts as a specific inhibitor of DNA synthesis, thus preventing cell division without affecting other metabolic activities. This way, viable cells start the replication process but cell division is prevented. As a result, they appear elongated and/or thicker after incubation.

It has been shown that Legionella spp. VBNC cells potentially resuscitate,

150 (Garcia et al., 2007; Ducret et al., 2014; Dietersdorfer et al., 2018). Consequently,

151 the foremost objective of this research was to optimize and apply DVC-FISH 
152 technique for the specific detection of viable and in all likelihood potentially

153 infectious Legionella spp. and L. pneumophila cells harboured by FLA from

154 wastewater and drinking water samples. The viability of the bacteria within FLA 155 was also investigated by standard culture methods. 


\section{MATERIALS AND METHODS}

\subsection{Sample collection}

A total of 55 samples (30 reclaimed wastewater and 25 drinking water) were collected. Wastewater samples were taken from the final disinfected (UV, chlorine) effluent of two wastewater treatment plants in a Mediterranean area from Spain. All of these reclaimed wastewater samples are available mainly for agriculture. Drinking water samples were collected from both public drinking water sources and different domestic units located in the East of Spain.

\subsection{Isolation of free-living amoebae}

Samples were collected into sterile bottles and processed within a maximum time of 2 hours. The residual free chlorine measurement of each drinking water sample was carried out by Spectroquant Nova 60 system (Merck, Germany).

One litre of wastewater and five litres of drinking water samples were filtered in duplicate through $3 \mu \mathrm{m}$ pore size nitrocellulose filters (Whatman, Maidstone, England). Membranes were placed face down on Non-Nutrient-Agar (Iovieno et al., 2010)] and incubated at $28^{\circ} \mathrm{C}$ for $24 \mathrm{~h}$. For drinking water samples, NNA plates were added with $0.1 \mathrm{ml}$ of a suspension of Escherichia coli heated at $100^{\circ} \mathrm{C}$ for 15 min. Filters were removed after $24 \mathrm{~h}$ and plates continued the incubation at $28^{\circ} \mathrm{C}$. NNA plates were controlled in order to observe FLA growth by phase contrast and inverted microscopy for 4 weeks. Then, NNA plates' content was collected by adding PAS solution and using a sterile cell scraper only if FLA growth was observed. One of the duplicate NNA plates was used to detect intra-amoebic Legionella spp. cells (section 2.3) and the other to detect two of the considered most widespread FLA: Acanthamoeba spp. and Vermamoeba vermiformis (section 2.4).

\subsection{Detection of intra-amoebic Legionella spp.}

Once NNA plates' content was collected, it was concentrated by centrifugation (500g, $3 \mathrm{~min}$ ) and the sediment was resuspended in $500 \mu \mathrm{l}$ of PAS solution Thereafter, FLA-external bacteria were treated using sodium hypochlorite at a concentration of 104 ppm for $1 \mathrm{~h}$ (Moreno-Mesonero et al., 2016) in order to kill them. Finally, hypochlorite was removed performing 3 washes with phosphate- 
190 buffered saline (PBS) and finally resuspended in $1.1 \mathrm{ml}$ of the same buffer. Aliquots

191 of $1.1 \mathrm{ml}$ were analysed by DVC-FISH method and culture as explained in 2.3.1 and

$192 \quad 2.3 .2$ sections, respectively, in order to detect intra-amoebic Legionella spp. and $L$.

193 pneumophila cells.

\subsubsection{DVC-FISH}

Optimization of DVC incubation was previously performed with pure cultures of the reference Legionella pneumophila CECT 7109 strain (Spanish Type Culture Collection) and an environmental Legionella spp. strain which belonged to our own collection. DVC optimization was performed by testing different antibiotics which belonged to the quinolones group (novobiocine and ciprofloxacin), at concentrations ranging from 0.5 to $8 \mathrm{mg} / \mathrm{l}$ and at different incubation times: 3,6 and 24 h. Briefly, 24 h Legionella spp. and L. pneumophila BCYE (buffered charcoal yeast extract; Oxoid, United Kingdom) cultures were inoculated in PBS buffer to reach a concentration of $10^{6}$ cells $/ \mathrm{ml}$. One $\mathrm{ml}$ of the suspension was inoculated into $9 \mathrm{ml}$ of the different DVC media tubes (Brucella broth supplemented with $5 \%$ fetal bovine serum (FBS) (PAA Laboratories, Austria) and piruvate (0.025\%)), each containing the different antibiotic concentrations above cited and incubated at $37^{\circ} \mathrm{C}$ for the different specified times. A DVC tube without antibiotic was also inoculated with $1 \mathrm{ml}$ of Legionella spp. and L. pneumophila suspension as a control assay.

212 DVC tubes were centrifuged at $8000 \mathrm{rpm}$ for $10 \mathrm{~min}$ and the pellet was 213 resuspended in $250 \mu \mathrm{l}$ of PBS. Then, $750 \mu \mathrm{l}$ of $4 \%$ paraformaldehyde (PFA) were

214 added to each one and they were incubated at $4^{\circ} \mathrm{C}$ for at least $2.5 \mathrm{~h}$ in order to fix 215 them. Afterwards, cells were washed twice using PBS to remove the remaining PFA 216 and resuspended in ethanol and PBS (1:1). Thereafter, hybridization was carried 217 out by depositing $10 \mu \mathrm{l}$ of each trial on the wells of hybridization slides and 218 hybridized as previously described by Moreno et al. (2003). To achieve the double 219 identification of both Legionella spp. and L. pneumophila, two different probes were used: LEG705: 5'-CTG GTG TTC CTT CCG ATC-3' which is complementary to a region of the 16S rRNA gene of members of the Legionellaceae family (Manz et al., 1995) and LEGPNE1: 5'-ATC TGA CCG TCC CAG GTT-3', an specific probe for the 
detection of L. pneumophila, which is complementary to a variable domain of the 16S rRNA gene of this bacteria (Grimm et al., 1998). Probes were synthesized and labelled with 6-FAM (6-Carboxyfluorescein) and CY3 respectively, by TIB Molbiol (Berlin, Germany). In order to avoid unspecific hybridization of the probes, the hybridization buffer contained a $35 \%$ of formamide.

Hybridization slides were washed under darkness in washing solution $(0.10 \mathrm{M}$ $\mathrm{NaCl}, 0.02 \mathrm{HCl}$-Tris, $0.01 \% \mathrm{SDS}$ and $0.005 \mathrm{M} \mathrm{EDTA}$ ) at $48^{\circ} \mathrm{C}$ for $15 \mathrm{~min}$. Finally, washing solution was removed from slides using distilled water and they were allowed to air-dry. Then, they were mounted in Vectashield ${ }^{\circledR}$ mounting medium (Vector Laboratories, UK) between the coverslip and the slide and were visualized using an Olympus BX 50 fluorescence microscope with the filters U-MWB, U-MWIB and U-MWIG.

\section{Samples}

One $\mathrm{ml}$ of the sodium hypochlorite-treated samples was added to $9 \mathrm{ml}$ of the optimized DVC broth, i.e. with $0.5 \mathrm{mg} / \mathrm{l}$ of novobiocine antibiotic. Samples were incubated at the optimal tested conditions, i.e. $37^{\circ} \mathrm{C}$ under aerobic conditions for $24 \mathrm{~h}$. After incubation, DVC tubes were centrifuged and resuspended in PBS as above described. Then, samples were fixed and hybridized as aforementioned. A pure culture of fixed L. pneumophila cells incubated for $24 \mathrm{~h}$ under DVC conditions

\subsubsection{Culture}

The existence of culturable intra-amoebic Legionella spp. cells was detected by cultivating a portion of $100 \mu \mathrm{l}$ of the sodium hypochlorite-treated samples on BCYE agar. Samples were incubated for 2-10 days at $37^{\circ} \mathrm{C}$ under aerobic conditions. Suspicious Legionella spp. colonies were picked and subsequently identified by FISH analysis as described in section 2.3.1.

\subsection{Detection of Acanthamoeba spp. and Vermamoeba vermiformis}

In order to detect the FLA Acanthamoeba spp. and V. vermiformis, each plate content was collected as explained above and concentrated in $500 \mu \mathrm{l}$ of PBS. DNA was subsequently extracted using GeneJET ${ }^{\text {TM }}$ Genomic DNA Purification Kit 
256 (Thermo Scientific, Germany) following the cultured mammalian cells DNA extraction protocol increasing from 10 to 30 minutes the incubation time at $56^{\circ} \mathrm{C}$ for cell lysis (Moreno-Mesonero et al., 2016). DNA was eluted in $50 \mu \mathrm{l}$ of the provided elution buffer and stored at $-20^{\circ} \mathrm{C}$ until use.

Afterwards, specific Acanthamoeba spp. and V. vermiformis TaqMan and SYBR Green-based qPCRs, respectively, were performed.

For the specific detection of Acanthamoeba spp., AcantF900: 5'-CCC AGA TCG TTT ACC GTG AA-3' and AcantR1100: 5'-TAA ATA TTA ATG CCC CCA ACT ATC C-3' primers were used to amplify a $180 \mathrm{bp}$ fragment of Acanthamoeba spp. 18S rRNA gene and the TaqMan probe AcantP1000: 5'-Cy5-CT GCC ACC GAA TAC ATT AGC ATG G-BHQ3-3' for its detection. The reaction was carried out in LightCycler ${ }^{\circledR} 2.0$ Instrument (Roche Applied Science, Spain) in a final volume of $20 \mu \mathrm{l}$, which contained $4 \mu \mathrm{l}$ of LightCycler® TaqMan ${ }^{\circledR}$ Master Reaction mix (Roche Applied Science, Spain), $0.8 \mu \mathrm{l}$ of each primer (10 $\mu \mathrm{M}$ stock solution), $0.4 \mu \mathrm{l}$ of the probe (10 $\mu \mathrm{M}$ stock solution), $0.4 \mu \mathrm{l}$ of BSA ( $1 \mathrm{mg} / \mathrm{ml}$ stock solution) and $3 \mu$ l of DNA template. The amplification consisted of an initial denaturalization step at $95^{\circ} \mathrm{C}$ for $10 \mathrm{~min}$ followed by 40 cycles of: $95^{\circ} \mathrm{C}$ for $10 \mathrm{~s}, 63^{\circ} \mathrm{C}$ for $8 \mathrm{~s}$ and $72^{\circ} \mathrm{C}$ for $7 \mathrm{~s}$; and finally, one cycle at $40^{\circ} \mathrm{C}$ for $30 \mathrm{~s}$ (Qvarnstrom et al., 2006).

For the specific detection of $V$. vermiformis, Hv1227F: 5'-TTA CGA GGT CAG GAC ACT GT-3' and Hv1728R: 5'-GAC CAT CCG GAG TTC TCG-3' primers were used for the amplification of a $502 \mathrm{bp}$ fragment of $V$. vermiformis 18S rRNA gene. The reaction was performed in a final volume of $20 \mu \mathrm{l}$, which contained $2 \mu \mathrm{l}$ of LightCycler® FastStart DNA Master SYBR Green I (Roche Applied Science, Spain), $0.4 \mu \mathrm{l}$ of each primer $\left(10 \mu \mathrm{M}\right.$ stock solution), 2,4 $\mu \mathrm{l}$ of $\mathrm{MgCl}_{2}$ (25 $\mathrm{mM}$ stock solution), $2 \mu \mathrm{l}$ of BSA ( $4 \mathrm{mg} / \mathrm{ml}$ stock solution) and $4 \mu \mathrm{l}$ of DNA template. The amplification consisted of an initial denaturalization step at $95^{\circ} \mathrm{C}$ for $10 \mathrm{~min}$ followed by 40 cycles of: $95^{\circ} \mathrm{C}$ for $10 \mathrm{~s}, 56^{\circ} \mathrm{C}$ for $10 \mathrm{~s}$ and $72^{\circ} \mathrm{C}$ for $25 \mathrm{~s}$; and finally, one cycle at $40^{\circ} \mathrm{C}$ for $30 \mathrm{~s}$. At the end of each run, a melting curve analysis was performed (Kuiper et al., 2006).

For both qPCRs, a positive control with DNA of either A castellanii or $V$. vermiformis and a negative control in which DNA was substituted for ultrapure water were added to each qPCR run. 


\section{RESULTS AND DISCUSION}

Legionella is the causative agent of legionellosis, which is a severe form of pneumonia and can be acquired through aerosols inhalation. Although different disinfection processes are applied to eliminate Legionella from water, it has been detected in different water sources. Since this pathogenic bacterium should be sensitive to all these treatments, it is plausible that it can be protected by FLA in these aquatic environments, where FLA are frequently found. Furthermore, these FLA probably act as a vector or, in another words, "Trojan Horse" for the bacteria, thus facilitating human infection. This way, the goal of this work is to identify these viable and potentially pathogenic cells of Legionella spp. and L. pneumophila internalized inside FLA isolated from reclaimed and drinking water.

In a total of $29(52.7 \%)$ out of the 55 processed samples it was possible to observe FLA growth. Specifically, wastewater samples, which were taken after tertiary disinfection treatment, showed FLA positive cultures in 20 (66.7\%) out of the 30 processed samples, while drinking water samples yielded FLA positive cultures in $9(36.0 \%)$ out of the 25 processed samples (Table 1 ).

Morphological characterization of the different isolated FLA by microscopy is an arduous task, since many of them have similar morphologies and, therefore, cannot be unequivocally identified by just observing them. This is why in this work two of the most common FLA found in water were molecularly detected by means of qPCR, although many different FLA morphologies were observed under the phase contrast microscope, thus indicating the presence of FLA different from Acanthamoeba spp. and V. vermiformis. Acanthamoeba spp., which comprises many different species indistinguishable by the used technique, was globally detected in $25(86.2 \%)$ out of the 29 water FLA-positive samples. Concretely, Acanthamoeba spp. was detected in 17 (85.0\%) out of the 20 wastewater FLA-positive samples and in $8(88.9 \%)$ out of the 9 drinking water FLA-positive samples (Table 1). In the case of V. vermiformis, this FLA was successfully detected in 7 (24.1\%) out of the 29 water FLA-positive samples. In wastewater, this FLA was detected in 5 (25.0\%) out of the 20 FLA-positive samples, and in drinking water, $V$. vermiformis was detected in $2(22.2 \%)$ out of the 9 FLA-positive samples (Table 1$)$.

These results are in line with other studies also carried out in Spain in which Acanthamoeba spp. was detected by qPCR in almost all of the processed samples, 
exactly in $87.5 \%$ and $93.7 \%$ of wastewater and drinking water samples, respectively (Magnet et al., 2012; Magnet et al., 2013). V. vermiformis distribution has not been as extensively studied as that of Acanthamoeba spp., although it is well known that the former FLA is a frequent component of fresh surface water (Kuiper et al., 2006). It has been detected in different aquatic environments, in which wastewater (García et al., 2013; Ramírez et al., 2014) and drinking water distribution systems (Nazar et al., 2012; Montalbano Di Filippo et al., 2015) are included.

The fact that FLA have been found in reclaimed wastewater after tertiary disinfection treatment and drinking water in this study matches with the results derived from Magnet et al. (2013) work. They detected Acanthamoeba spp. in wastewater and drinking water in both raw and after treatment, thus indicating that this treatment was not effective for the removal of FLA. This seems to suggest that the presence of FLA in water treatment plant effluents could be due to FLA resistance to the carried out treatments as well as to the fact that they could survive and grow in biofilms present in the distribution system (Thomas and Ashbolt, 2011).

In this work, the presence of Legionella spp. and L. pneumophila was only tested in those samples which showed positive FLA growth in order to exclusively detect FLA-internalized bacteria. This way, all FLA-positive cultures were collected and treated with a very high concentration of sodium hypochlorite so that all bacteria outside FLA were killed. The same treatment was previously applied by our group in order to identify FLA-internalized $H$. pylori cells from both wastewater and drinking water origins (Moreno-Mesonero et al., 2017).

The interaction of Legionella spp. with FLA has been widely studied. García et al. (2007) showed reciprocal benefits in the interaction of the FLA Acanthamoeba polyphaga with L. penumophila in their resistance to water disinfection. Magnet et al. (2015) carried out a study in Spain in which water from different sources such as drinking water and wastewater treatment plants and natural ponds were analysed. This study concluded that environmental Acanthamoeba seems to be widely infected by Legionella spp. Also, Legionella spp. was confirmed as part of the FLA microbiome when drinking water samples containing FLA were analysed by means of $16 \mathrm{~S}$ pyrosequencing (Delafont et al., 2013). However, although it has been 
largely shown in vitro that Legionella spp. is able to multiply within FLA, to our knowledge no study has shown FLA-internalized Legionella spp. viability by means of molecular techniques in reclaimed and drinking water samples.

FISH technique has been reported as an efficient method, better than culture, to detect Legionella in biofilms and cooling towers (Zeybek et al., 2017). This technique is not influenced by the inhibitor substances present in the environment, is able to identify VBNC cells, which have lost their ability to grow on synthetic media, and it allows to observe the morphology and even count in situ the cells present in the sample. The combination of DVC, a procedure which allows viable bacteria to elongate in presence of nutrients and whose division are inhibited due to a gyrase blocker, with FISH, which is performed on rRNA-targeted sequences, has been proved effective in detecting and identifying viable cells in mixed microbial communities such as rivers (Tirodimos et al., 2014), wastewater (Moreno and Ferrús, 2012), water distribution systems (Mezule et al., 2013; Santiago et al., 2015) and even inside FLA isolated from wastewater and drinking water (Moreno-Mesonero et al., 2017). Moreover, Legionella DVC-FISH technique has the advantage of its rapidity compared to the classical standard culture method of these bacteria. While a complete Legionella DVC-FISH analysis could be performed in less than 30 hours, its standard cultivation method and identification requires up to 10 days. As far as we are aware, this is the first study in which viable Legionella spp. and L. pneumophila have been detected simultaneously using this molecular technique in water systems. Specific probes used in this assay have been previously published (Manz et al., 1995; Grimm et al., 1998). Despite their specificity has also been assayed in those reports, in this work, the possible match of the probes with a rRNA region of other microorganism different from Legionella has been tested in silico by the alignment analysis of the probes through NCBI database. Although both probes resulted specific for Legionella spp. (LEG705) and L. pneumophila(LEGPNE1) in silico, hybridization reaction was performed under restrictive conditions (35\% formamide).

The previous incubation of cells in DVC broth, which has a DNA gyrase inhibitor agent (novobiocine, a quinolone antibiotic) allows differentiating viable and nonviable cells after FISH detection. Novobiocine antibiotic at a concentration of 0.5 $\mathrm{mg} / \mathrm{l}$ and after $24 \mathrm{~h}$ incubation time yielded the best results, since Legionella cells 
became the most elongated and the concentration of cells remained the same. The number of cells in DVC control tube increased and cells size remained the same, not being elongated.

By means of DVC-FISH, the presence of viable internalized Legionella spp. cells (elongated more than twice the original size) was observed in a total of $20(69.0 \%)$ samples out of the 29 FLA-positive ones (Figure 1). Some FLA were also observed as presenting a low auto-fluorescence, mainly with U-MWIB filter. However, that background fluorescence did not interfere with Legionella spp. or L. pneumophila hybridized cells visualization. Specifically, metabolically activated Legionella spp. cells were detected in $14(70.0 \%)$ out of the 20 FLA-positive reclaimed wastewater samples and in $6(66.7 \%)$ out of the 9 FLA-positive drinking water samples. When hypochlorite-treated FLA-positive samples were hybridized with L. pneumophila, a total of 14 (48.3\%) samples contained viable L. pneumophila cells. Concretely, 10 $(50.0 \%)$ out of the 20 FLA-positive wastewater samples and $4(44.4 \%)$ out of the 9 FLA-positive drinking water samples exhibited viable internalized L. pneumophila cells (Table 1).

Another useful technique which could have been used apart from DVC-FISH is PCR (Polymerase Chain Reaction) due to its sensitivity and rapidity. However, the latter cannot detect living cells. To do so, it has to be combined with viability dyes such as propidium monoazide (PMA) or ethidium monoazide (EMA) which irreversibly bind to external DNA or to DNA from membrane-damaged cells and block these in any subsequent PCR amplification (Nocker et al., 2006). Nevertheless, in this study samples have been treated with a high concentration of sodium hypochlorite in order to kill FLA-external bacteria. Thus, PMA or EMA will only prevent amplification of non-internalized cells because they would not enter inside FLA, not being able to distinguish between live and dead FLA-internalized cells (Moreno-Mesonero et al., 2016). This is the reason why DVC-FISH technique was the chosen molecular technique to study the viability of Legionella spp. and $L$. pneumophila FLA-internalized cells in water samples.

The high percentage of viable Legionella positive samples confirm, as other authors suggested (Jjemba et al., 2010) that this bacteria is able to survive inside protozoa, where it is protected against chlorine. Therefore, both the exposure to reclaimed wastewater and drinking water could be a risk of Legionella infection. As 
concluded by Jjemba et al. (2010) even though no Legionella outbreaks have been directly related to reclaimed water systems, effective measures should be stabilised in order to control Legionella and protozoa in these systems to avoid future public health problems, since some of them are human pathogens.

As results indicate, although the pathogenic bacteria L. pneumophila has been identified inside FLA in the processed samples, other species than L. pneumophila were present in the cultured FLA, some of which may not be pathogenic. As Muder and $\mathrm{Yu}$ (2002) reported, potentially pathogenic Legionella species other than $L$. pneumophila could be present inside FLA, since it has been previously shown that they are able to survive and even multiply inside them. Thus, future studies designing specific probes for FISH detection of other non-L. pneumophila species should be addressed in order to know the real exposure to pathogenic and nonpathogenic Legionella species in water systems. Moreover, it has been previously proved that growth and multiplication of Legionella spp. are both improved when they are within FLA or in nutrient-rich biofilms (Brown and Barker 1999; Thomas et al. 2004; Lau and Ashbolt 2009). For this reason, the identification of these bacteria, some of which could be human pathogens, inside FLA in water systems should be exhaustively performed, since FLA could help bacteria to reach humans.

When the classical culture technique was used to cultivate an aliquot of the samples, typical Legionella colonies were retrieved from both reclaimed wastewater and potable water samples in a total of $8(27.6 \%)$ samples out of the 29 FLA-positive ones. Concretely, 7 (35.0\%) out of the 20 FLA-positive wastewater samples and only one (11.1\%) out of the 9 FLA-positive drinking water samples showed the presence of viable cultivable Legionella spp. cells (Table 1). Presumptive colonies were fixed and hybridized using the previously specified probes and conditions and all of them were identified as L. pneumophila.

Besides the fact that the standard culture method needs up to 10 days for its analysis, the presence of viable and internalized Legionella spp. cells could be unnoticed because of inhibition due to competitive microbiota or the presence of VBNC cells (Kirschner, 2016). Legionella spp. can acquire the VBNC state under unfavourable conditions. In this state, cells are unable to form colonies on synthetic media as they do in normal conditions. This way, in these cases, standard methods are of no use, since they would yield false negative results. Moreover, culture 
454 methods are neither useful for some pathogenic species, such as $L$. fallonii, $L$. 455 rowbothamii or $L$. drozanskii, previously known as "Legionella-like amebal 456 pathogens" (LLAP), which can be preferably detected by molecular methods 457 because they are non-cuturable and obligate intracellular species found in water 458 environments which grow very low on agar media (Huang et al., 2011).

459 In this study, DVC-FISH technique allowed to identify in a rapid and specific way 460 the presence of viable Legionella spp and L. pneumophila cells inside the different 461 isolated FLA from drinking water and wastewater samples, among which 462 Acanthamoeba spp. and V. vermiformis were included. This showed that this 463 technique is a powerful tool when detecting metabolically active intra-amoebic 464 Legionella spp. cells in water systems which could pose a risk for human health. 
466 This study has been supported by First research projects funding (PAID-06-18),

467 Vice-Rectorate for Research, Innovation and Transfer of "Universitat Politècnica de 468 València" (UPV), València, Spain

469 


\section{REFERENCES}

471 Abdelhady, H., Garduño, R.A. 2013. The progeny of Legionella pneumophila in 472 human macrophages shows unique developmental traits. FEMS Microbiol Lett, 349: 99-107. https://doi.org/10.1111/1574-6968.12300

474 Adiba, S., Nizak, C., van Baalen, M., Denamur, E., Depaulis, F. 2010. From grazing resistance to pathogenesis: the coincidental evolution of virulence factors. PLoS ONE, 5:e11882. https://doi.org/10.1371/journal.pone.0011882

Akya, A., Pointon, A., Thomas, C. 2009. Viability of Listeria monocytogenes in coculture with Acanthamoeba spp. FEMS Microbiol Ecol, 70: 20-29. https://doi.org/10.1111/j.1574-6941.2009.00736.x

Allegra, S., Berger, F., Berthelot, P., Grattard, F., Pozzetto B., Riffard S. 2008. Use of flow cytometry to monitor Legionella viability. Appl Environ Microbiol, 74: 78137816. https://doi.org/10.1128/AEM.01364-08

Barker, J., Brown, M.R.W. 1994. Trojan horses of the microbial world: protozoa and the survival of bacterial pathogens in the environment. Microbiology, 140:12531259.

Bartram, J., Chartlier, Y., Lee, J.V., Pond, K. Surman-Lee, S. 2007. Legionella and the prevention of legionellosis. Geneva: World Health Organization.

Borella, P., Montagna, M.T., Romano-Spica, V., Stampi, S., Stancanelli, G., Triassi,M., Neglia, R., Marchesi, I., Fantuzzi, G., Tatò, D., Napoli, C., Quaranta, G., Laurenti, P. Leoni, E., De Luca, G., Ossi, C., Moro, M., Ribera D'Alcalà, G. 2004. Legionella infection risk from domestic hot water. Emerg Infect Dis, 10: 457-464.

Borella, P., Montagna, M.T., Stampi, S., Stancanelli, G., Romano-Spica, V., Triassi, M., Marchesi, I., Bargellini, A., Tatò, D., Napoli, C., Zanetti, F., Leoni, E., Moro, M., Scaltriti, S., Ribera D'Alcalà, G., Santarpia, R., Boccia, S. 2005. Legionella contamination in hot water of Italian hotels. Appl Environ Microbiol, 71: 5805-5813. https://doi.org/10.1128/AEM.71.10.5805-5813.2005

498 Brown, M.R., Barker, J. 1999. Unexplored reservoirs of pathogenic bacteria: protozoa 
500 Bui, X.T., Winding, A., Qvortrup, K., Wolff, A., Bang, D.D., Creuzenet, C. 2012. Survival

501 of Campylobacter jejuni in co-culture with Acanthamoeba castellanii: role of 502 amoeba-mediated depletion of dissolved oxygen. Environ Microbiol, 14: 2034-2047. https://doi.org/10.1111/j.1462-2920.2011.02655.x

504 Burstein, D., Amaro, F., Zusman, T., Lifshitz, Z., Cohen, O., Gilbert, J.A., Pupko, T., 505 Shuman, H., Segal, G. 2016. Genomic analysis of 38 Legionella species identifies 506 large and diverse effector repertoires. Nat Genet, 48: 167-175. 507 https://doi.org/10.1038/ng.3481

508 Byrne, B., Swanson, M.S. 1998. Expression of Legionella pneumophila virulence 509 traits in response to growth conditions. Infect Immun, 66: 3029-3034.

510 Cirillo, J.D., Falkow, S., Tompkins, L.S. 1999. Growth of Legionella pneumophila in 511 Acanthamoeba castellanii enhaces invasion. Infect Immun, 62: 3254-3261.

512 Conza, L., Casati, S., Gaia, V. 2013. Detection limits of Legionella pneumophila in 513 environmental samples after co-culture with Acanthamoeba polyphaga. BMC 514 Microbiol, 13: 49. https://doi.org/10.1186/1471-2180-13-49

515 Declerck, P, Behets, J., van Hoef, V., Ollevier, F. 2007. Detection of Legionella spp. and 516 some of their amoeba hosts in floating biofilms from anthropogenic and natural 517 aquatic environments. Water Res 41: 3159-3167.

518 https://doi.org/10.1016/j.watres.2007.04.011

519 Delafont, V., Brouke, A., Bouchon, D., Moulin, L., Héchard, Y. 2013. Microbiome of 520 free-living amoebae isolated from drinking water. Water Res, 47: 6958-6965. https://doi.org/10.1016/j.watres.2013.07.047

522 Dietersdorfer, E., Kirschner, A., Schrammel, B., Ohradanova-Repic, A., Stockinger, H., 523 Sommer, R., Walochnik, J., Cervero-Aragó, S. 2018. Starved viable but non524 culturable (VBNC) Legionella strains can infect and replicate in amoebae and 525 human macrophages. Water Res, 141: 428-438. 526 https://doi.org/10.1016/j.watres.2018.01.058

527 Ducret, A., Chabalier, M., Dukan, S. 2014. Characterization and resuscitation of 
528 "non-culturable" cells of Legionella pneumophila. BMC Microbiol. 14: 3. 529 https://doi.org/10.1186/1471-2180-14-3

530 Füchslin, H.P.., Kötzsch, S., Keserue, H.A., Egli, T. 2010. Rapid and quantitative 531 detection of Legionella pneumophila applying immunomagnetic separation and 532 flow cytometry. Cytometry A: 77: 264-274. https://doi.org/10.1002/cyto.a.20858

533 García, A., Goñi, P., Cieloszyk, J., Fernández, M.T., Calvo-Beguería, L., Rubio, E., Fillat, 534 M.F., Peleato, M.L., Clavel, A. 2013. Identification of free-living amoebae and 535 amoeba-associated bacteria from reservoirs and water treatment plants by 536 molecular techniques. Environ Sci Technol, 47: 3132-3140. 537 https://doi.org/10.1021/es400160k

538 García, M.T. Jones S., Pelaz, C., Millar, R.D., Abu Kwaik Y. 2007 Acanthamoeba 539 polyphaga resuscitates viable non-culturable Legionella pneumophila after 540 disinfection. Enviro. Microbiol, 9: 1267-1277. https://doi.org/10.1111/j.14622920.2007.01245.x

542 Garduño, R.A., Garduño, E., Hiltz, M., Hoffman P.S. 2002. Intracellular growth of Legionella pneumophila gives rise to a differentiated form dissimilar to stationaryphase forms. Infect Immun, 70: 6273-6283. https://doi.org/10.1128/IAI.70.11.6273-6283.2002

546 Gomez-Valero, L., Rusniok, C., Rolando, M., Neou, M., Dervins-Ravault, D., Demirtas, 547 J., Rouy, Z., Moore, R.J., Chen, H., Petty, N.K., Jarraud, S., Etienne, J., Steinert, M., 548 Heuner, K., Gribaldo, S., Médigue, C., Glöckner, G., Hartland, E.L., Buchrieser, C. 2014. 549 Comparative analyses of Legionella species identifies genetic features of strains 550 causing Legionnaires' disease. Genome Biol, 505. 551 https://doi.org/10.1186/s13059-014-0505-0

552 Graells, T., Ishak, H., Larsson, M., Guy, L. 2018. The all-intracellular order 553 Legionellales is unexpectedly diverse, globally distributed and lowly abundant. 554 FEMS Microl Ecol, https://doi.org/10.1093/femsle/fiy185

555 Greub, G, Raoult, D. 2004. Microorganisms resistant to free-living amoebae. Clin 556 Microbiol Rev, 17: 413-433. https://doi.org/10.1128/CMR.17.2.413-433.2004 
557 Grimm, D., Merkert, H., Ludwig, W., Schleifer, K.H., Hacker, J., Brand, B.C. 1998. 558 Specific detection of Legionella pneumophila: construction of a new 16S rRNA 559 targeted oligonucleotide probe. Appl Environ Microbiol, 64: 2686-2690.

560 Huang, S.W., Hsu, B.M., Chen, N.H., Huang, C.C., Huang, K.H., Chen, J.S., Kao, P.M. 561 2011. Isolation and identification of Legionella and their host amoebae from weak 562 alkaline carbonate spring water using a culture method combined with PCR. 563 Parasitol Res, 109: 1233-1241. https://doi.org/10.1007/s00436-011-2366-8

564 Iovieno, A., Ledee, D.R., Miller, D., Alfonso, E.C. 2010. Detection of bacterial 565 endosymbionts in clinical Acanthamoeba isolates. Ophthalmology, 117: 445-452. 566 https://doi.org/10.1016/j.ophtha.2009.08.033

567 Jjemba, P.K., Weinrich, L.A., Cheng, W., Giraldo, E., Lechevallier, M.W. 2010. 568 Regrowth of potential opportunistic pathogens and algae in reclaimed-water 569 distribution systems. Appl Environ Microbiol, 76: 4169-4178. $570 \quad$ https://doi.org/10.1128/AEM.03147-09

571 Khan, N.A. 2006. Acanthamoeba: biology and increasing importance in human 572 health. FEMS Microbiol Rev, 30: 564-595. https://doi.org/10.1111/j.15746976.2006.00023.x

574 Kirschner A.K.T. 2016. Determination of viable legionellae in engineered water 575 systems: Do we find what we are looking for? Water Res. 93: 276-288. https://doi.org/10.1016/j.watres.2016.02.016.

577 Kogure, K., Simidu, U., Taga, N. 1979. A tentative direct microscopic method for 578 counting living marine bacteria. Can J Microbiol, 25: 415-420.

579 Kuiper, M.W., Valster, R.M., Wullings, B.A., Boonstra, H., Smidt, H., van der Kooij, D. 580 2006. Quantitative detection of the free-living amoeba Hartmannella vermiformis in 581 surface water by using real-time PCR. Appl Environ Microbiol, 72: 582 https://doi.org/5750-5756.10.1128/AEM.00085-06

583 Lau, H.Y., Ashbolt, N.J. 2009. The role of biofilms and protozoa in Legionella 584 pathogenesis: implications for drinking water. J Appl Microbiol, 107: 368-378. 585 https://doi.org/10.1016/10.1111/j.1365-2672.2009.04208.x 
586 Magnet, A., Fenoy, S., Galván, A.L., Izquierdo, F., Rueda, C., Fernández-Vadillo, C., Del 587 Águila, C. 2013. A year long study of the presence of free living amoeba in Spain. 588 Water Res, 47: 6966-6972. https://doi.org/10.1016/j.watres.2013.09.065

589 Magnet, A., Galván, A.L., Fenoy, S., Izquierdo, F., Rueda, C., Fernández-Vadillo, C., 590 Pérez-Irezábal, J., Bandyopadhyay, K., Visvesvara, G.S., da Silva, A.J., del Águila, C. 591 2012. Molecular characterization of Acanthamoeba isolated in water treatment 592 plants and comparison with clinical isolates. Parasitol Res, 111: 383-392. 593 https://doi.org/10.1007/s00436-012-2849-2

594 Magnet, A., Peralta, R.H., Gomes, T.S., Izquierdo, F., Fernández-Vadillo, C., Galván, 595 A.L., Pozuelo, M.J., Pelaz, C., Fenoy, S., Del Águila, C. 2015. Vectorial role of 596 Acanthamoeba in Legionella propagation in water for human use. Sci Total Environ, 505: 889-895. https://doi.org/10.1016/j.scitotenv.2014.10.064

598 Manz, W., Amann, R., Szewzyk, R., Szewzyk, U., Stenström, T.A., Hutzler, P., Schleifer, 599 K.H. 1995. In situ identification of Legionellaceae using 16S rRNA targeted 600 oligonucleotide probes and confocal laser scanning microscopy. Microbiology, 141: $601 \quad 29-39$.

602 Mezule, L., Larsson, S., Juhna, T. 2013. Application of DVC-FISH method in tracking 603 Escherichia coli in drinking water distribution networks. Drink Water Eng Sci, 6: 25604 31. https://doi.org/10.5194/dwes-6-25-2013

605 Moens, E. 2002. The prevention and control of Legionella spp. (including 606 Legionnaires'disease) in food factories. Trends Food Sci Tech, 13: 380-384. 607 https://doi.org/10.1016/S0924-2244(02)00246-7

608 Montalbano Di Filippo, M., Santoro, M., Lovreglio, P., Monno, R., Capolongo, C., Calia, 609 C. Fumarola, L., D’Alfonso, R., Berrilli, F., Di Cave, D. 2015. Isolation and molecular 610 characterization of free-living amoebae from different water sources in Italy. Int J 611 Environ Res Public Health, 12: 3417-3427. 612 https://doi.org/10.3390/ijerph120403417

613 Moreno, Y., Ferrús, M.A. 2012. Specific detection of cultivable Helicobacter pylori 614 cells from wastewater treatment plants. Helicobacter, 17: 327-332. 615 https://doi.org/10.1111/j.1523-5378.2012.00961.x 
616 Moreno, Y., Ferrús, M.A., Alonso, J.L., Jiménez, A., Hernández, J. 2003. Use of

617 fluorescent in situ hibridization to evidence the presence of Helicobacter pylori in

618 water. Water Res, 37: 2251-2256. https://doi.org/10.1016/S0043-1354(02)00624-

$619 \underline{3}$

620 Moreno-Mesonero, L., Moreno, Y., Alonso, J.L., Ferrús, M.A. 2016. DVC-FISH and 621 PMA-qPCR techniques to assess the survival of Helicobacter pylori inside 622 Acanthamoeba castellanii. Res Microbiol, 167: 29-34. 623 https://doi.org/10.1016/j.resmic.2015.08.002

624 Moreno-Mesonero, L., Moreno, Y., Alonso, J.L., Ferrús, M.A. 2017. Detection of viable 625 Helicobacter pylori inside free-living amoebae in wastewater and drinking water 626 samples from Eastern Spain. Environ Microbiol, 19: 4103-4112. 627 https://doi.org/10.1111/1462-2920.13856

628 Muder, R.R., Yu, V.L. 2002. Infection due to Legionella species other than $L$. 629 pneumophila. Clin Infect Dis, 35: 990-998. https://doi.org/10.1086/342884

630 Nazar, M., Haghighi, A., Taghipour, N., Ortega-Rivas, A., Tahvildar-Biderouni, F., 631 Mojarad, E.N., Eftekhar, M. 2012. Molecular identification of Hartmannella 632 vermiformis and Vannella persistens from man-made recreational water 633 environments, Tehran, Iran. Parasitol Res, 111: 835-839. 634 https://doi.org/10.1007/s00436-012-2906-x

635 Nocker, A., Cheung, C., Camper, A.K. 2006. Comparison of propidium monoazide 636 with ethidium monoazide for differentiation of live vs dead bacteria by selective 637 removal of DNA from dead cells. J Microbiol Methods, 67: 310-320.

638 Oliver, J.D. 2010. Recent findings on the viable but nonculturable state in 639 pathogenic bacteria. FEMS Microbiol Rev, 34: 415-425.

640 https://doi.org/10.1111/j.1574-6976.2009.00200.x

641 Qvarnstrom, Y., Visvesvara, G.S., Sriram, R., da Silva, A.J. 2006. Multiplex real-time 642 PCR assay for simultaneous detection of Acanthamoeba spp., Balamuthia 643 mandrillaris, and Naegleria fowleri. J Clin Microbiol, 44: 3589-3595. 644 https://doi.org/10.1128/JCM.00875-06 
645 Ramírez, E., Robles, E., Martínez, B., Ayala, R., Sainz, G., Martínez, M.E., González, 646 M.E. 2014. Distribution of free-living amoebae in a treatment system of textile 647 industrial $\quad$ wastewater. Exp Parasitol, 145: S34-S38. 648 https://doi.org/10.1016/j.exppara.2014.07.006

649 Robertson, P., Abdelhady, H., Garduño, R.A. 2014. The many forms of a pleomorphic 650 bacterial pathogen-the developmental network of Legionella pneumophila. Front 651 Microbiol. 5: 670. https://doi.org/10.3389/fmicb.2014.00670

652 Santiago, P., Moreno, Y., Ferrús, M.A. 2015. Identification of viable Helicobacter 653 pylori in drinking water supplies by cultural and molecular techniques. 654 Helicobacter, 20: 252-259. https://doi.org/10.1111/hel.12205

655 Scaturro M., Fontana S., Dell'eva, I., Helfer, F., Marchio, M., Stefanetti, M.V., Cavallaro, 656 M., Miglietta, M., Montagna, M.T., De Giglio, O., Cuna, T., Chetti, L., Sabattini, M.A.B., 657 Carlotti, M., Viggiani, M., Stenico, A., Romanin, E., Bonanni, E., Ottaviano, C., Franzin, 658 L., Avanzini, C., Demarie, V., Corbella, M., Cambieri, P., Marone, P., Rota, M.C., Bella, 659 A., Ricci, M.L. 2016. A multicenter study of viable PCR using propidium monoazide 660 to detect Legionella in water samples. Diagn Microbiol Infect Dis, 85: 283-288. 661 https://doi.org/10.1016/j.diagmicrobio.2016.04.009

662 Steinert, M., Emödy, L., Amann, R., Hacker, J. 1997. Resuscitation of viable but 663 nonculturable Legionella pneumophila Philadelphia JR32 by Acanthamoeba 664 castellanii. Appl Environ Microbiol, 63: 2047-2053

665 Thomas, J.M., Ashbolt, N.J. 2011. Do free-living amoebae in treated drinking water 666 systems present an emerging health risk? Environ Sci Technol, 45: 860-869. 667 https://doi.org/10.1021/es102876y

668 Thomas, V., Bouchez, T., Nicolas, V., Robert, S., Loret, J.F., Lévi Y. 2004. Amoebae in 669 domestic water systems: resistance to disinfection treatments and implication in 670 Legionella persistence. J Appl Microbiol, 97: 950-963. 671 https://doi.org/10.1111/j.1365-2672.2004.02391.x

672 Tirodimos, I., Bobos, M., Kazakos, E., Haidich, A.B., Dardavessis, T., Kostopoulos, I., 673 Arvanitidou, M. 2014. Molecular detection of Helicobacter pylori in a large 674 Mediterranean river, by direct viable count fluorescent in situ hybridization (DVC- 
675 FISH). $\quad J \quad$ Water $\quad$ Health, $\quad$ 868-873.

676 https://doi.org/10.1016/10.2166/wh.2014.171

677 Trabelsi, H., Dendana, F., Sellami, A., Sellami, H., Cheikhrouhou, F., Neji, S., Makni, F., 678 Ayadi, A. 2012. Pathogenic free-living amoebae: epidemiology and clinical review. 679 Pathol. Biol. 6: 399-405. https://doi.org/10.1016/j.patbio.2012.03.002

680 Zeybek, Z., Gungor, N.D., Turetgen, I. 2017. Investigation of heterotrophic bacteria, 681 Legionella and Free-Living amoeba in cooling tower samples by FISH and culture 682 methods. Eur J Biol, 76:7-13. 
684 Table 1. Obtained results of wastewater and drinking water samples

\begin{tabular}{|c|c|c|c|c|c|c|c|c|}
\hline \multirow{30}{*}{ 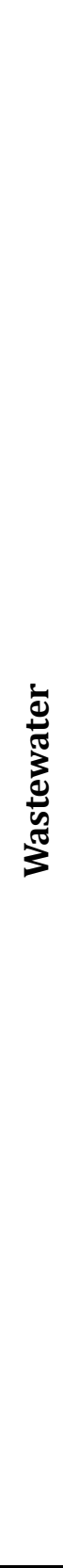 } & 1 & WW1 & + & + & - & + & + & + \\
\hline & 2 & WW2 & + & + & - & + & - & - \\
\hline & 3 & WW3 & - & $\mathrm{N} / \mathrm{A}$ & $\mathrm{N} / \mathrm{A}$ & $\mathrm{N} / \mathrm{A}$ & $\mathrm{N} / \mathrm{A}$ & $\mathrm{N} / \mathrm{A}$ \\
\hline & 4 & WW4 & + & + & - & + & + & + \\
\hline & 5 & WW5 & + & - & + & - & - & - \\
\hline & 6 & WW6 & - & $\mathrm{N} / \mathrm{A}$ & $\mathrm{N} / \mathrm{A}$ & $\mathrm{N} / \mathrm{A}$ & $\mathrm{N} / \mathrm{A}$ & $\mathrm{N} / \mathrm{A}$ \\
\hline & 7 & WW7 & + & + & + & + & + & + \\
\hline & 8 & WW8 & + & + & - & + & - & - \\
\hline & 9 & WW9 & + & + & + & + & + & + \\
\hline & 10 & WW10 & - & $\mathrm{N} / \mathrm{A}$ & $\mathrm{N} / \mathrm{A}$ & $\mathrm{N} / \mathrm{A}$ & $\mathrm{N} / \mathrm{A}$ & $\mathrm{N} / \mathrm{A}$ \\
\hline & 11 & WW11 & - & $\mathrm{N} / \mathrm{A}$ & $\mathrm{N} / \mathrm{A}$ & $\mathrm{N} / \mathrm{A}$ & $\mathrm{N} / \mathrm{A}$ & $\mathrm{N} / \mathrm{A}$ \\
\hline & 12 & WW12 & + & + & - & - & - & - \\
\hline & 13 & WW13 & - & $\mathrm{N} / \mathrm{A}$ & $\mathrm{N} / \mathrm{A}$ & $\mathrm{N} / \mathrm{A}$ & $\mathrm{N} / \mathrm{A}$ & $\mathrm{N} / \mathrm{A}$ \\
\hline & 14 & WW14 & + & + & - & - & - & - \\
\hline & 15 & WW15 & + & + & - & + & - & - \\
\hline & 16 & WW16 & + & + & + & + & + & + \\
\hline & 17 & WW17 & + & + & - & - & - & - \\
\hline & 18 & WW18 & - & $\mathrm{N} / \mathrm{A}$ & $\mathrm{N} / \mathrm{A}$ & $\mathrm{N} / \mathrm{A}$ & $\mathrm{N} / \mathrm{A}$ & N/A \\
\hline & 19 & WW19 & + & + & - & + & + & - \\
\hline & 20 & WW20 & - & $\mathrm{N} / \mathrm{A}$ & $\mathrm{N} / \mathrm{A}$ & $\mathrm{N} / \mathrm{A}$ & $\mathrm{N} / \mathrm{A}$ & $\mathrm{N} / \mathrm{A}$ \\
\hline & 21 & WW21 & + & - & + & + & - & - \\
\hline & 22 & WW22 & + & + & - & + & + & + \\
\hline & 23 & WW23 & + & - & - & - & - & - \\
\hline & 24 & WW24 & + & + & - & + & + & - \\
\hline & 25 & WW25 & + & + & - & + & + & - \\
\hline & 26 & WW26 & - & $\mathrm{N} / \mathrm{A}$ & $\mathrm{N} / \mathrm{A}$ & $\mathrm{N} / \mathrm{A}$ & $\mathrm{N} / \mathrm{A}$ & N/A \\
\hline & 27 & WW27 & - & $\mathrm{N} / \mathrm{A}$ & $\mathrm{N} / \mathrm{A}$ & N/A & $\mathrm{N} / \mathrm{A}$ & $\mathrm{N} / \mathrm{A}$ \\
\hline & 28 & WW28 & + & + & - & + & + & + \\
\hline & 29 & WW29 & + & + & - & - & - & - \\
\hline & 30 & WW30 & - & $\mathrm{N} / \mathrm{A}$ & $\mathrm{N} / \mathrm{A}$ & $\mathrm{N} / \mathrm{A}$ & $\mathrm{N} / \mathrm{A}$ & N/A \\
\hline \multirow{8}{*}{ 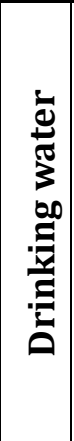 } & 31 & DW1 & - & $\mathrm{N} / \mathrm{A}$ & $\mathrm{N} / \mathrm{A}$ & $\mathrm{N} / \mathrm{A}$ & $\mathrm{N} / \mathrm{A}$ & $\mathrm{N} / \mathrm{A}$ \\
\hline & 32 & DW2 & + & + & - & + & - & - \\
\hline & 33 & DW3 & - & $\mathrm{N} / \mathrm{A}$ & $\mathrm{N} / \mathrm{A}$ & N/A & $\mathrm{N} / \mathrm{A}$ & N/A \\
\hline & 34 & DW4 & - & $\mathrm{N} / \mathrm{A}$ & $\mathrm{N} / \mathrm{A}$ & $\mathrm{N} / \mathrm{A}$ & $\mathrm{N} / \mathrm{A}$ & N/A \\
\hline & 35 & DW5 & - & $\mathrm{N} / \mathrm{A}$ & $\mathrm{N} / \mathrm{A}$ & $\mathrm{N} / \mathrm{A}$ & $\mathrm{N} / \mathrm{A}$ & $\mathrm{N} / \mathrm{A}$ \\
\hline & 36 & DW6 & + & - & + & + & + & + \\
\hline & 37 & DW7 & + & + & - & - & - & - \\
\hline & 38 & DW8 & - & $\mathrm{N} / \mathrm{A}$ & $\mathrm{N} / \mathrm{A}$ & $\mathrm{N} / \mathrm{A}$ & $\mathrm{N} / \mathrm{A}$ & $\mathrm{N} / \mathrm{A}$ \\
\hline
\end{tabular}


SAMPLES SAMPLE ID FLA Acanthamoeba spp. V. vermiformis DVC-FISH spp DVC-FISH pn Culture

\begin{tabular}{|c|c|c|c|c|c|c|c|}
\hline 39 & DW9 & - & $\mathrm{N} / \mathrm{A}$ & $\mathrm{N} / \mathrm{A}$ & $\mathrm{N} / \mathrm{A}$ & $\mathrm{N} / \mathrm{A}$ & $\mathrm{N} / \mathrm{A}$ \\
\hline 40 & DW10 & - & $\mathrm{N} / \mathrm{A}$ & $\mathrm{N} / \mathrm{A}$ & $\mathrm{N} / \mathrm{A}$ & $\mathrm{N} / \mathrm{A}$ & N/A \\
\hline 41 & DW11 & - & $\mathrm{N} / \mathrm{A}$ & $\mathrm{N} / \mathrm{A}$ & $\mathrm{N} / \mathrm{A}$ & $\mathrm{N} / \mathrm{A}$ & N/A \\
\hline 42 & DW12 & + & + & + & + & + & - \\
\hline 43 & DW13 & - & $\mathrm{N} / \mathrm{A}$ & $\mathrm{N} / \mathrm{A}$ & $\mathrm{N} / \mathrm{A}$ & $\mathrm{N} / \mathrm{A}$ & $\mathrm{N} / \mathrm{A}$ \\
\hline 44 & DW14 & - & $\mathrm{N} / \mathrm{A}$ & $\mathrm{N} / \mathrm{A}$ & $\mathrm{N} / \mathrm{A}$ & $\mathrm{N} / \mathrm{A}$ & $\mathrm{N} / \mathrm{A}$ \\
\hline 45 & DW15 & + & + & - & - & - & - \\
\hline 46 & DW16 & - & $\mathrm{N} / \mathrm{A}$ & $\mathrm{N} / \mathrm{A}$ & $\mathrm{N} / \mathrm{A}$ & $\mathrm{N} / \mathrm{A}$ & $\mathrm{N} / \mathrm{A}$ \\
\hline 47 & DW17 & + & + & - & - & - & - \\
\hline 48 & DW18 & - & $\mathrm{N} / \mathrm{A}$ & $\mathrm{N} / \mathrm{A}$ & $\mathrm{N} / \mathrm{A}$ & $\mathrm{N} / \mathrm{A}$ & $\mathrm{N} / \mathrm{A}$ \\
\hline 49 & DW19 & - & $\mathrm{N} / \mathrm{A}$ & $\mathrm{N} / \mathrm{A}$ & $\mathrm{N} / \mathrm{A}$ & $\mathrm{N} / \mathrm{A}$ & $\mathrm{N} / \mathrm{A}$ \\
\hline 50 & DW20 & + & + & - & + & - & - \\
\hline 51 & DW21 & + & + & - & + & + & - \\
\hline 52 & DW22 & - & $\mathrm{N} / \mathrm{A}$ & $\mathrm{N} / \mathrm{A}$ & $\mathrm{N} / \mathrm{A}$ & $\mathrm{N} / \mathrm{A}$ & $\mathrm{N} / \mathrm{A}$ \\
\hline 53 & DW23 & - & $\mathrm{N} / \mathrm{A}$ & $\mathrm{N} / \mathrm{A}$ & $\mathrm{N} / \mathrm{A}$ & $\mathrm{N} / \mathrm{A}$ & $\mathrm{N} / \mathrm{A}$ \\
\hline 54 & DW24 & - & $\mathrm{N} / \mathrm{A}$ & $\mathrm{N} / \mathrm{A}$ & $\mathrm{N} / \mathrm{A}$ & $\mathrm{N} / \mathrm{A}$ & N/A \\
\hline 55 & DW25 & + & + & - & + & + & - \\
\hline
\end{tabular}

686 +: positive result; -: negative result, N/A: not applicable 


\section{Legend to figures}

688 Fig.1. Simultaneous identification of both Legionella spp. and L. pneumophila by FISH hybridization 689 with the probes LEG705-FAM (green fluorescence) and LEGPNE1-CY3 (red fluorescence) observed 690 by double filter U-MWB (red and green fluorescence). (A) Reclaimed wastewater sample; (B) 691 drinking water sample. 